\title{
A Mild Type Propofol Infusion Syndrome Presentation in Critical Care
}

\author{
Yoğun Bakımda Hafif Șiddetli Bir Propofol Infüzyon Sendromu
}

\author{
Aysu Hayriye Tezcan', Mesut Öterkuș', İlksen Dönmez', Ömür Öztürk², Zeynep Yavuzekinci' \\ ${ }^{1}$ Kafkas Üniversitesi Tip Fakültesi, Anesteziyoloji ve Reanimasyon Anabilim Dalı, Kars; ${ }^{2}$ Çanakkale 18 Mart Üniversitesi T⿰р Fakültesi, \\ Anesteziyoloji ve Reanimasyon Anabilim Dal, Çanakkale, Türkiye
}

\begin{abstract}
Propofol infusion syndrome (PRIS) is a rare but fatal disease. It was occured mostly after high dose of propofol infusions for long times. Metabolic acidosis, hypotension, myoglobinuria, elevated muscle and liver enzymes, cardiac arrhythmias, cardiac arrest are common manifestations of the syndrome. This case report concluded a mild type of PRIS which was presented after low dose (25-50 mcg/kg/min) infusion for long time. In this case significant metabolic acidosis, hypotension and arrhythmias were not detected during drug infusion. Syndrome was manifested with only significantly elevated AST, ALT, CK, CKMB, LDH levels. Persistence of these findings during propofol infusion without patient's further clinical impairments defined as mild type of PRIS. In addition, the improvements in the biochemical parameters deteriorated after the drug was discontinued proved the validity of our diagnosis.
\end{abstract}

Key words: propofol; critical care; sedation

\section{ÖZET}

Propofol infüzyon sendromu (PRiS) nadir ama ölümcül bir hastalıktır. Bu sendrom çoğunlukla ilacın yüksek dozda uzun süreli infüzyonundan sonra olușur. Metabolik asidoz, hipotansiyon, miyoglobinüri, artmıș karaciğer ve kas enzimleri, kardiyak aritmiler ve kalp durması sendromun genel özellikleridir. Bu olgu sunumunda uzun süreli düșük doz (25-50 mcg/kg/dk) ilaç infüzyonundan sonra ortaya çıkan hafif tipte bir PRiS tartıșılmıștır. Bu olguda ilaç infüzyonu esnasında ciddi metabolik asidoz, hipotansiyon yada aritmi gözlenmemiștir. Sadece AST, ALT, CK, CKMB, LDH düzeylerinde artıș saptanmıștır. Propofol infüzyonu boyunca hastanın hiç klinik durumunda bozulma olmadan sadece bahsedilen parametrelerdeki bozukluğun devam etmesi olguyu hafif tipte bir PRiS olarak tanımlamamıza neden oldu. Ek olarak ilacın kesilmesi sonrası bozulan kimyasal parametrelerdeki düzelmeler teșhisimizin doğruluğunu da kanıtlamıș oldu.

Anahtar kelimeler: propofol; yoğun bakım; sedasyon

Aysu Hayrive Tezcan, Kafkas Üniversitesi T⿰р Fakültesi, Să̆llk Uygulama Araștrrma Hastanesi Kars - Türkiye, Tel.05326735711 Email.aysndr@gmail.com Geliş Taribi: 09.01.2017 • Kabul Taribi: 03.03.2017

\section{Introduction}

Propofol is a widely used anesthetic and sedative drug that with its safety profile in critical care. Minimal side effects, short half-life, minimum residual congitive effects are the reason of the propofol selection. Frequently, propofol is used via intravenous infusion in critical care and long term infusion may cause a fatal complication named as propofol infusion syndrome (PRIS). Lactic acidosis, hypotension, myoglobinuria, rhabdomyolysis, cardiac arrhythmia and cardiovascular collaps are the clinical findings of the syndrome ${ }^{1}$. Even the exact therapy of the syndrome is unknown, early diagnosis may increase survival rate. We try to demonstrate an early diagnosed mild type PRIS in critical care.

\section{Case Report}

46 year old male patient was brought to the hospital for sudden loss of conciousness. His physical examination showed that his glasgow coma scale was $3 \mathrm{E}$ (patient was intubated in ambulance and mechanically ventilated), direct and consensual pupillary reflexes were negative, spontaneous breathing was weak and irregular. In history, there is none of systemic comorbidities and trauma. His blood pressure was 190/100 $\mathrm{mmHg}$, pulse rate was $99 / \mathrm{min}$, peripheral oxygen saturation was $94 \%$. Cranial computed tomography (CT) demonstrated mesencephalic hemorrhage and significant brain edema. The patient was scheduled for external ventricular drainage system (EVD) placement. After surgery, patient was sedatized in critical care with midazolam infusion. In critical care, all vital signs (electrocardiogram, blood pressure, pulse rate, peripheral oxygen saturation, temperature) and 
urine output were monitorized. Daily complete blood count, biochemical variables, arterial blood gases were measured (myoglobin levels could not measured in our hospital). For significant brain edema, daily mannitol and dexamethasone therapy was initiated. Ceftriaxone is administered for postoperative antibiotic prophylaxis. Intravenous antihypertensive therapy was administered for brain perfusion protection. Intraarterial catheterization was applied for closed blood pressure monitorization. None of cerebral edema reduction was detected in control cranial CT in the third day of the hospitalization. Secondary of significant brain edema and resistant hypertension, propofol infusion was added to the therapy. The intravenous infusion was maintained between $25-50 \mathrm{mcg} / \mathrm{kg} / \mathrm{min}$. Patient was evaluated daily by neurosurgeons. Biochemical parameter analyses showed significant elevations in creatine kinase $(\mathrm{CK})$, muscle band of creatine kinase (CKMB), lactate dehydrogenase (LDH), aspartate aminotransferase (AST), alanine aminotransferase (ALT) levels at the second day of the propofol infusion. $(\mathrm{CK}=6524 \mathrm{IU} / \mathrm{L}, \mathrm{CKMB}=73 \mathrm{U} / \mathrm{L}, \mathrm{LDH}=584$ $\mathrm{IU} / \mathrm{L}, \mathrm{AST}=311 \mathrm{U} / \mathrm{L}, \mathrm{ALT}=109 \mathrm{U} / \mathrm{L})$. Lactic acidosis or troponin level elevation was not demonstrated at this day. At the second day deep hypotension was not demonstrated and secondary to significant brain edema propofol infusion was continued. Similar clinical and laboratory findings were recorded in the third day of the infusion. At the forth day of the infusion CK, CKMB, LDH, ALT, AST levels elevated more significantly $(\mathrm{CK}=11014 \mathrm{IU} / \mathrm{L}, \mathrm{CKMB}=104 \mathrm{U} / \mathrm{L}$, $\mathrm{LDH}=883 \mathrm{IU} / \mathrm{L}, \mathrm{ALT}=214 \mathrm{U} / \mathrm{L}, \mathrm{AST}=660 \mathrm{U} / \mathrm{L})$. At the fourth day lactic acidosis or troponin level elevation was not demonstrated still. Heamodynamic variables were still stable. Secondary to these biochemical parameters' alteration, propofol infusion was terminated. The biochemical parameters started to decrease at the 24th hour of the infusion cessation. Five days after the infusion termination biochemical parameters reached almost baseline levels. Unchanged mesencephalone hematoma, slightly decreased brain edema was demonstrated by control cranial CT scans but none of clinically neurologic impairment was detected. Daily clinical and laboratory assessments continued. At the 19th day of the hospitalization, hypotension was occured secondary to sepsis and dopamine, norepinephrine infusions were initiated. And at the 20th day of the hospitalization sudden cardiac arrest occured and patient died.

\section{Discussion}

Several case reports were published about PRIS. In these reports; lactic acidosis, rhabdomyolysis, elevated liver enzymes, hypotension, fatal cardiac arryhthmias were most seen clinical presentations ${ }^{1-5}$. Authors concluded that PRIS occured after long term infusions ( 48 hours) and high drug doses $(>4 \mathrm{mg} / \mathrm{kg} / \mathrm{h})^{6}$. In our case report patient received lower doses of propofol but infusion persisted for longer that mentioned above. Laboratory parameters' alteration started at the second day of the infusion as mentioned in literature but any clinical deterioration could not observed. Hypotention or malign arryhthmias were not observed. The clinical and heamodynamic stability encourage the clinicians to continue propofol infusion because there was still need to sedate the patient for significant brain edema. But significantly daily increasing liver enzymes, $\mathrm{CK}$ and $\mathrm{CKMB}$ alterations resulted the termination of propofol infusion at fourth day. The absence of the clinical impairment or lactic acidosis may be secondary to low doses of the drug. Authors concluded that clinicians must be aware of PRIS by following all these biochemical markers mentioned above and absence of lactic acidosis do not exlude PRIS. In this case report patients biochemical parameters were decreased to baseline values in a few days after the termination of the drug. But patient had a fatal disease like mesencephalic hemorrhage still and sepsis added to the process which caused the death of the patient.

In critical care to be male, younger than $18 \mathrm{yr}$ old, to receive vasopressor drugs, metabolic acidosis, rhabdomyolysis are the main mortality risk factors of PRIS ${ }^{6}$. Our case consists only one risk factor such being male during propofol infusion. Besides, our patient was collapsed thirteen days after propofol infusion termination. Authors concluded that not propofol infusion, intracranial pathology and sepsis were the reasons of the death. It was thought that propofol impaired mitochondrial respiratory chain reactions and energy production get insufficient especially in heart and muscle cells. These pathophysiology manifested with high AST, $\mathrm{CK}, \mathrm{CKMB}, \mathrm{LDH}$ levels and myoglobinuria like our case. The most important deficiency of our case report was not to demonstrate myoglobin levels secondary to hospital's laboratory limitations. The literature can not demonstrate exact therapy for the PRIS. Cessation of the drug infusion and supportive therapies were recommended $^{7}$. In this case, these recommendations were applied and sufficed to get better laboratory findings with stable heamodynamic changes. 
In conclusion, we want to emphasize that, clinicians must be aware of different degrees of PRIS like our case. PRIS may not be always manifest as its perfect definition which was defined above. Muscle enzymes' alterations alone may be the early signs of the syndrome. In these conditions; closed follow up, consideration of mortality risk factors and true timing for cessation of the drug infusion may increase survival.

\section{References}

1. Kam PCA, Cardone D. Propofol infusion syndrome. Anaesthesia 2007;62(7):690-701.

2. Cremer OL, Moons KG, Bouman EA, Kruijswijk JE, de Smet AMG, Kalkman CJ. Long-term propofol infusion and cardiac failure in adult head-injured patients. Lancet 2001;357(9250):117-18.
3. Ernest D, French C. Propofol infusion syndrome--report of an adult fatality. Anaesth Intensive Care 2003;31(3):316-319.

4. Stelow EB, Johari VP, Smith SA, Crosson JT, Apple FS. Propofol-associated rhabdomyolysis with cardiac involvement in adults: chemical and anatomic findings. Clin Chem 2000 Apr; 46(4):577-81.

5. Fudickar A, Bein B, Tonner PH. Propofol infusion syndrome in anaesthesia and intensive care medicine. Curr Opin Anaesthesiol 2006;19(4):404-10.

6. Fudickar A, Bein B. Propofol infusion syndrome: update of clinical manifestation and pathophysiology. Minerva Anestesiol 2009;75(5):339-44.

7. Vasile B, Rasulo F, Candiani A, Latronico N. The pathophysiology of propofol infusion syndrome: a simple name for a complex syndrome. Intensive Care Med 2003;29(9):1417-25. 